\title{
Nucleobase Derivatives as Building Blocks to Form Ru(II)-Based Complexes with High Cytotoxicity
}

Diogo E. L. Carvalho, ${ }^{\dagger, \|}$ Katia M. Oliveira, ${ }^{\dagger}\|\|$ Larissa M. Bomfim, ${ }^{\dagger}$ Milena B. P. Soares, Daniel P. Bezerra, ${ }^{\ddagger}$ Alzir A. Batista, ${ }^{\S}$ and Rodrigo S. Correa* ${ }^{*}+\infty$

\footnotetext{
${ }^{\dagger}$ Departamento de Química, Instituto de Ciências Exatas e Biológicas-Campus Morro do Cruzeiro, Universidade Federal de Ouro Preto-UFOP, CEP 35400-000 Ouro Preto, MG, Brazil

${ }^{\ddagger}$ Fundação Oswaldo Cruz, Gonçalo Moniz, Rua Waldemar Falcão, 121, Candeal, CEP 40296-710 Salvador, BA, Brazil

${ }^{\S}$ Departamento de Química, Universidade Federal de São Carlos-UFSCar, Rod. Washington Luís, km 235 - SP-310, CEP 13565-905 São Carlos, SP, Brazil

Supporting Information
}

ABSTRACT: Two new Ru(II)-based complexes containing 2-thiouracil derivatives, known as 2-thiouracil (2TU) and 6-methyl-2-thiouracil (6m2TU), were synthesized using cis,trans- $\left[\mathrm{RuCl}_{2}\left(\mathrm{PPh}_{3}\right)_{2}\right.$ (bipy)] as a precursor. The obtained compounds with a general formula trans-[Ru(2TU) $\left(\mathrm{PPh}_{3}\right)_{2}($ bipy $\left.)\right] \mathrm{PF}_{6}$ (1) and trans- $[\mathrm{Ru}(6 \mathrm{~m} 2 \mathrm{TU})$ $\left(\mathrm{PPh}_{3}\right)_{2}($ bipy $\left.)\right] \mathrm{PF}_{6}$ (2) were characterized by analytical techniques such as NMR, UV-vis, and IR spectroscopies, elementary analysis, mass spectrometry, and singlecrystal X-ray diffraction. Moreover, the investigation of the complexes-DNA interaction were carried out using spectrophotometric titrations and showed that the complexes present a weak interaction with this biomolecule. The compounds were evaluated against HL-60, K-562, HepG2, and B16-F10 cancer cells and against noncancer cells (PBMCs). The results of the biological assay revealed that complex 2 is more promising than complex 1. Finally, the present study suggests that complexes $\mathbf{1}$ and $\mathbf{2}$ causes cell death by apoptosis, significantly increasing the percentage of apoptotic HL-60 cells, in which the compounds altered the cell cycle, reducing the cells in $G_{1} / G_{0}, G_{2} / M$, and $S$ phases.

\section{INTRODUCTION}

Uracil is a well-known pyrimidine nucleobase used as an RNA building block. Pyrimidines and purine derivatives comprise an important molecular framework to drug design, in which structural modifications on nucleobase derivatives can lead to the formation of compounds with pharmacological properties. ${ }^{1,2}$ An example involving purine is 6-mercaptopurine (6$\mathrm{MP}$ ), an antineoplastic drug that acts as an antimetabolite agent. ${ }^{3,4}$ Concerning the uracil moiety, a widely studied compound called 5-fluorouracil (5FU) has also been used as an anticancer drug. ${ }^{5,6}$ Besides the molecular modification in the molecule ring, special attention has been directed toward the coordination of 5-fluorouracil and derivatives with transition metals. $^{7-9}$ As a consequence, many compounds containing these classes of molecules have been obtained to exhibit different physicochemical properties, and thus able to alter the effectiveness of the drug. ${ }^{10-13}$ Therefore, from the coordination point of view, several strategies in preparative inorganic chemistry have been widely investigated to coordinate a bioligand with a metal center to increase their biological potential. ${ }^{14-16}$

Recently, we have reported structural and biological studies with cationic $\mathrm{Ru}(\mathrm{II})$-thymine and $\mathrm{Ru}(\mathrm{II})$-5-fluorouracil complexes, and their promising properties such as metallodrug candidates, with high cytotoxic against cancer cells, have led to further studies in vivo. ${ }^{8}$ Moreover, neutral ruthenium(II)- based complexes containing two 2-thiouracil derivative ligands per metal center have been recently investigated, presenting promising results, mainly against leukemia HL-60 cells. ${ }^{19}$ Goitia and co-workers have reported that gold(I)/complex with 2-thiouracil exhibits excellent cytotoxic activity against PC-12 and NIH-3T3 cell lines. ${ }^{18}$ Thus, having in mind that $\mathrm{Ru}$ (II) complexes have been investigate in the development of compounds with anticancer properties, to evaluate the structural modification on biological properties of ruthenium complexes with 2-thiouracil derivatives, we present here the synthesis of two new monocationic complexes, expecting that they will have good cytotoxicity against cancer cells. ${ }^{19-24}$

\section{RESULTS AND DISCUSSION}

To obtain the desired complexes studied here, cis,trans$\left[\mathrm{RuCl}_{2}\left(\mathrm{PPh}_{3}\right)_{2}\right.$ (bipy) $]$ was used as precursor, which was obtained following the procedures described by Batista and co-workers. $^{25}$ The synthetic route of complexes $\mathbf{1}$ and $\mathbf{2}$ is represented in Scheme 1.

Given that there are few studies of ruthenium(II)-based complexes containing 2-thiouracil derivatives, the study of a new class of compound was performed. Owing to fact that

Received: June 26, 2019

Accepted: December 17, 2019

Published: January 3, 2020 
Scheme 1. Route of the Synthesis Used to Obtain Complexes 1 and 2
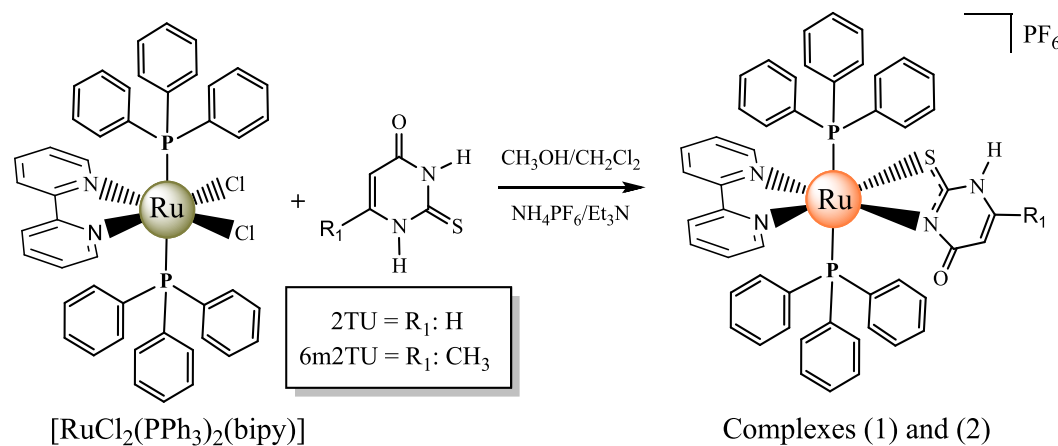

Complexes (1) and (2)

phosphinic ligands are able to stabilize the metal center and the possibility of coordinating only one 2-thiouracil ligands per metal center by exchanging two chloride ligands, giving rise to cationic complexes, complexes $\mathbf{1}$ and $\mathbf{2}$ were rationally designed.

Complexes 1 and 2 were characterized by physical and chemical techniques, especially X-ray crystallography. In addition, the DNA-interaction studies were performed by UV-vis spectrophotometric titration. Moreover, in vitro biological assays against human hepatocellular carcinoma (HepG2), human promyelocytic leukemia (HL-60), human chronic myelocytic leukemia (K-562), and mouse melanoma (B16-F10) were performed. Also, complexes 1 and 2 were tested against noncancer cells, known as human peripheral blood mononuclear cells, activated with concanavalin A, a human lymphoblast (PBMC).

The chemical versatility presented by thiouracil, or analogous, as a ligand has been attractive in the preparative inorganic chemistry field. Thus, to explore the reactivity of these ligands, which still remains underexplored in the literature, we used a precursor complex that allows the exchange of two chlorido by one negatively charged thiouracilderived ligand, acting as a bidentate ligand. As a result, one negative counterion is needed to stabilize the charge of the complex, such as $\mathrm{PF}_{6}^{-}$. The conductivity and elemental analysis confirm this hypothesis, as do the ${ }^{31} \mathrm{P}\left\{{ }^{1} \mathrm{H}\right\}$ NMR experiments. As can be seen, the precursor cis,trans$\left[\mathrm{RuCl}_{2}\left(\mathrm{PPh}_{3}\right)_{2}(\right.$ bipy $\left.)\right]$ shows a singlet in the ${ }^{31} \mathrm{P}\left\{{ }^{1} \mathrm{H}\right\}$ spectrum at $21.5 \mathrm{ppm}$, in dichloromethane $\left(\mathrm{CH}_{2} \mathrm{Cl}_{2}\right)$. On the other hand, complexes 1 and 2 both present just one singlet at 32.2 $\mathrm{ppm}$. The signals in the same region strongly suggest that complexes 1 and 2 show the same stereochemistry. It can be observed that the ${ }^{31} \mathrm{P}\left\{{ }^{1} \mathrm{H}\right\}$ NMR signal in both complexes have little influence by changing the $2 \mathrm{TU}$ ligand for the $6 \mathrm{~m} 2 \mathrm{TU}$ ligand. This behavior can occur because the phosphorus atom is trans positioned to another one and is poorly affected by the bipy and 2TU ligands located on the equatorial position (see Scheme 1). Compared with the other $\mathrm{Ru}(\mathrm{II}) /$ phosphinic complexes previously studied, it also reveals one singlet in the region of 30-35 ppm. On the other hand, the phosphorus in the cis configuration is deshielded, presenting chemical shifts around $50 \mathrm{ppm}^{26,27}$ The structures of complexes 1 and 2 change after incubation with DMSO solvent. The chemical modification was followed by ${ }^{31} \mathrm{P}$ NMR experiments for compounds $\mathbf{1}$ and $\mathbf{2}$ (see the spectra in the Supporting Information (SI)). It is suggested that these changes may be assigned to the exchange of one $\mathrm{PPh}_{3}$ ligand by one DMSO molecule. In this way, the signal of $\mathrm{PPh}_{3}$ free is observed at $6.77 \mathrm{ppm}$.
The $\mathrm{Ru}(\mathrm{II})$ complexes were also characterized by ${ }^{1} \mathrm{H}$ NMR studies (see SI). In the spectra for both compounds, the region ranging from 7.0 to $7.6 \mathrm{ppm}$ was assigned to the hydrogen atoms of the $\mathrm{PPh}_{3}$ ligands, while the hydrogen atoms of the bipy ligand occurred in the range of 11.5-7.7 ppm. For complex 1, the presence of a hydrogen linked to an $\mathrm{N} 1-\mathrm{H}$ nitrogen of the $2 \mathrm{TU}$ ligand is observed at $12.2 \mathrm{ppm}$, while the signals at 5.2 and $6.7 \mathrm{ppm}$ are attributed to the $\mathrm{H} 5$ and $\mathrm{H} 6$ atoms of $2 \mathrm{TU}$, respectively. Important information to assign the $\mathrm{N}-\mathrm{H}$ signal was obtained by the two-dimensional hydrogen spectrum $\left({ }^{1} \mathrm{H}-{ }^{1} \mathrm{H}\right.$ COSY) (see SI). The ${ }^{1} \mathrm{H}-{ }^{1} \mathrm{H}$ COSY spectrum of complex 1 reveals that there is a correlation between the atom $\mathrm{H} 6$ and $\mathrm{N} 1-\mathrm{H}$, as well as $\mathrm{H} 6$ and H5. Thus, the hydrogen atom $\mathrm{H} 1$ of the $\mathrm{N} 1$ atom is present in the structure, suggesting that the coordination occurred via N3-S, not via the $\mathrm{N} 1-\mathrm{S}$ mode. This behavior differs from the $\mathrm{Ru} /$ 2TU complexes previously reported. ${ }^{17}$

As proposed, the structures for complexes $\mathbf{1}$ and $\mathbf{2}$ include one thiouracil and one bipyridine ligand, as well as two $\mathrm{PPh}_{3}$ coordinated to $\mathrm{Ru}(\mathrm{II})$. Some comparisons with the structure of the $\left[\mathrm{Ru}(2 \mathrm{TU})_{2}\left(\mathrm{PPh}_{3}\right)_{2}\right]$ complex, previously reported ${ }^{17}$ can be made. For example, the stereochemistry has changed and there is a substitution of one thiouracil derivative by one bipyridine ligand, leaving the metal center slightly electron deficient due to the greater $\pi$-receptor character of bipyridine than that of the thiouracil ligand. This aspect can be seen by the cyclic voltammetry and differential pulse techniques. As a result of the $\pi$-receptor character of bipyridine, complexes $\mathbf{1}$ and $\mathbf{2}$ present higher redox potentials than the complexes $[\mathrm{Ru}-$ $\left.(2 \mathrm{TU})_{2}\left(\mathrm{PPh}_{3}\right)_{2}\right]$ without a bipy ligand. ${ }^{17}$ Cyclic and differential pulse voltammetries obtained for 1 and 2 reveal the $\mathrm{Ru}(\mathrm{II}) / \mathrm{Ru}$ (III) redox couple near $1000 \mathrm{mV}$, while the values found for the neutral complexes with two N-S chelating ligands present redox potentials lower than $1000 \mathrm{mV}$ (ranging from 600 to $800 \mathrm{mV}) .^{28}$ This may be the evidence that bipyridine-containing complexes are better stabilized in the $\mathrm{Ru}(\mathrm{II})$ oxidation state.

Additionally, the complexes were also characterized by highresolution mass experiments. Complexes 1 and $\mathbf{2}$ exhibit peaks in 909.1531 and $923.1698 \mathrm{Da}$, respectively, assigned to the theoretical values for $\mathrm{M}+(909.1527$ and $923.1684 \mathrm{Da}$ for 1 and $\mathbf{2}$, respectively). The mass spectra obtained for $\mathbf{1}$ and $\mathbf{2}$ can identify signals that are assigned to the $\mathrm{M}+-\mathrm{PPh}_{3}$ species, which can be expected, given that the $\mathrm{PPh}_{3}$ is monodentate and can be labialized.

The complexes were studied by infrared absorption spectroscopy (see Figures S10 and S11 and Table S3). The band referring to $v \mathrm{C}=\mathrm{O}$ stretching vibration changed slightly compared with free ligands. In the free ligands, $2 \mathrm{TU}$ and 
$6 \mathrm{~m} 2 \mathrm{TU}$ present the $v \mathrm{C}=\mathrm{O}$ stretching vibration at 1711 (for $2 \mathrm{TU}$ ) and $1674 \mathrm{~cm}^{-1}$ (for $6 \mathrm{~m} 2 \mathrm{TU}$ ), whereas in compounds 1 and 2 , the values found are 1657 and $1651 \mathrm{~cm}^{-1}$. Furthermore, all compounds present bands of $v \mathrm{C}=\mathrm{N}$ of the bipy and 2TU/ $6 \mathrm{~m} 2 \mathrm{TU}$ ligands. Analyzing the region of the spectrum in the range of 1400 to $1600 \mathrm{~cm}^{-1}$, it can be observed that in all complexes, signals at 1433 and $1481 \mathrm{~cm}^{-1}$ are present, which can be attributed to $v \mathrm{C}=\mathrm{C}$ stretching vibrations. Compared with the precursor complex, it can be seen that in the 1536 $\mathrm{cm}^{-1}$ region, there is a common band, which refers to the $v \mathrm{C}=\mathrm{N}$ stretching vibrations of the bipy ligand. Thus, it can be noted that in complexes $\mathbf{1}$ and $\mathbf{2}$, there are bands that occur at $1570 \mathrm{~cm}^{-1}$ and these may correspond to the $v \mathrm{C}=\mathrm{N}$ stretching vibration of the thiouracil derivative ligands. The band at around $840 \mathrm{~cm}^{-1}$ due to the $v \mathrm{P}-\mathrm{F}$ stretching vibration confirms the presence of $\mathrm{PF}_{6}^{-}$as a counterion.

In the present report, the molecular structures of complexes $\mathbf{1}$ and $\mathbf{2}$ were determined by single-crystal X-ray diffraction (Figure 1 and Table S1). The main bond lengths obtained for $\mathbf{1}$ and $\mathbf{2}$ (Table S2) reveal that the $\mathrm{Ru}-\mathrm{L}$ bond values, around the metal center, are similar in both complexes. This behavior is expected given that the stereochemistry is the same as that of the phosphorus atoms of the $\mathrm{PPh}_{3}$ ligand trans to each one.
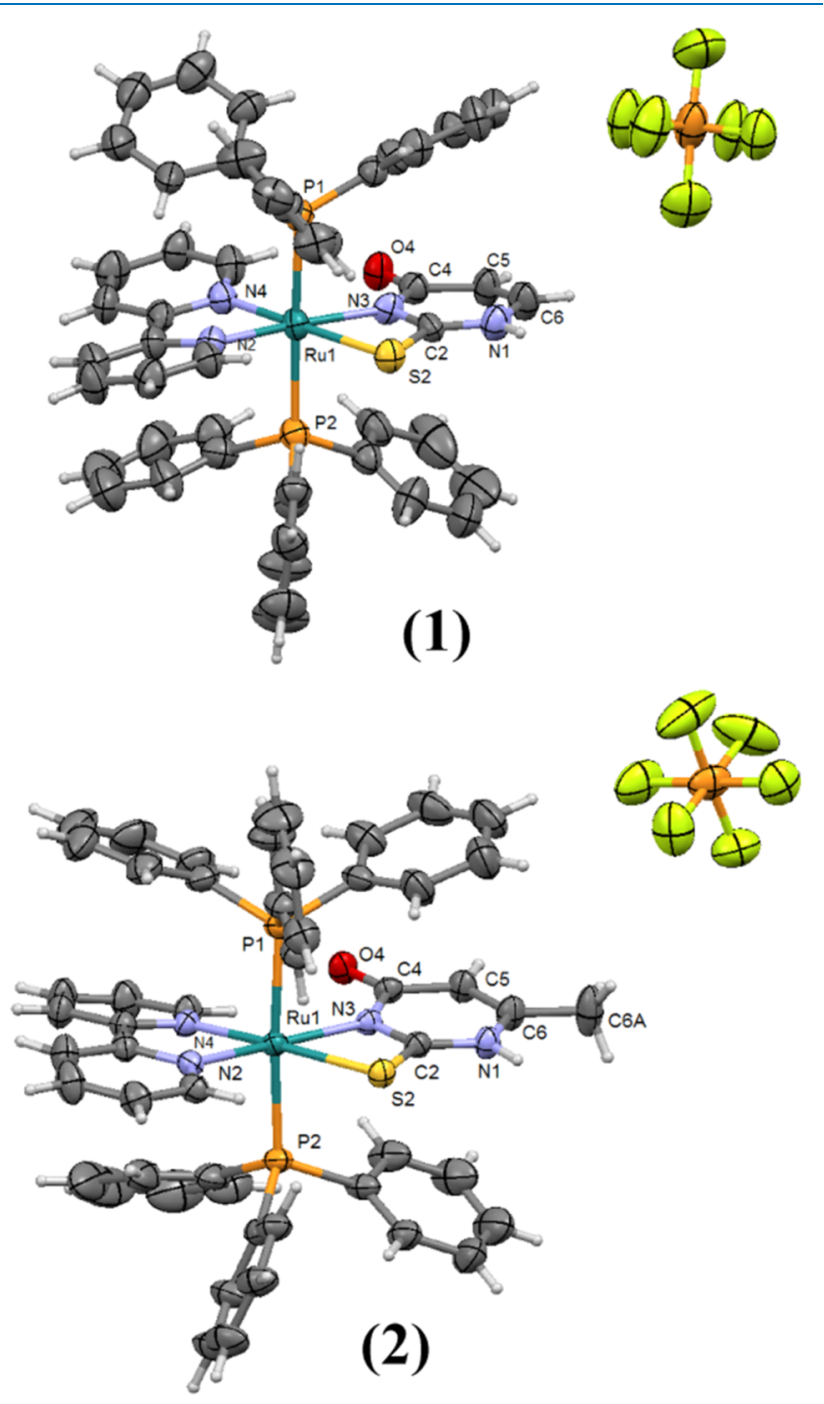

Figure 1. Crystal structures of complexes 1 and 2.
The nitrogen atoms of the bipy, labeled as N2 and N4, are trans to N3 and S2 atoms of thiouracil ligands, respectively. The X-ray diffraction results show that $2 \mathrm{TU}$ and $6 \mathrm{~m} 2 \mathrm{TU}$ are coordinated by the nitrogen atom $\mathrm{N} 3$ and sulfur, as bidentate. Mainly, in complex 2, the coordination involving the N3 atom contribute to decreasing the steric hindrance around the methyl group of position 6 , in $6 \mathrm{~m} 2 \mathrm{U}$. Interestingly, both complexes present intramolecular interactions between the $\mathrm{C}-$ $\mathrm{H}$ of the bipy ligand and the oxygen atom of the ligand 2thiouracil derivative $[\mathrm{C}-\mathrm{H}($ bipy $) \cdots \mathrm{O} 4]$. This behavior is important to stabilize the molecular structure of the complexes, allowing the coordination to occur through the N3 atom. As can be seen in Figure 1, the coordination involving the N1 atom and $\mathrm{S} 2$ atom will result in a steric hindrance between the $\mathrm{C}-\mathrm{H}_{\text {(bipy) }}$ and the $\mathrm{C}-\mathrm{H}$ of $2 \mathrm{TU}$ or the $-\mathrm{CH}_{3}$ of $2 \mathrm{TU}$, respectively.

The different coordinations of the $2 \mathrm{TU}$ and $6 \mathrm{~m} 2 \mathrm{TU}$ ligands in $\mathbf{1}$ and 2, compared with those of the previously reported complexes cis- $\left.\left[\mathrm{Ru}\left(\mathrm{PPh}_{3}\right)_{2}(\mathrm{TU})_{2}\right]\right]^{16}$ also contribute to the different intermolecular interaction patterns related to the cis$\left[\mathrm{Ru}\left(\mathrm{PPh}_{3}\right)_{2}(\mathrm{TU})_{2}\right]$ complexes. In the cis- $\left[\mathrm{Ru}\left(\mathrm{PPh}_{3}\right)_{2}(\mathrm{TU})_{2}\right]$ complexes, there is a formation of a pattern of type $\mathbf{R}_{2}^{2}(\mathbf{8})$ graph-set, forming dimeric bonds $\mathrm{N}-\mathrm{H} \cdots \mathrm{O}$. On the other hand, the two crystal structures reported here present the molecules forming intermolecular interactions linking the molecules as a chain, $\mathbf{C}_{2}^{2}(\mathbf{8})$ graph-set, involving the atoms $\mathrm{N} 1-\mathrm{H} \cdots \mathrm{O} 4$ (Figure 2).

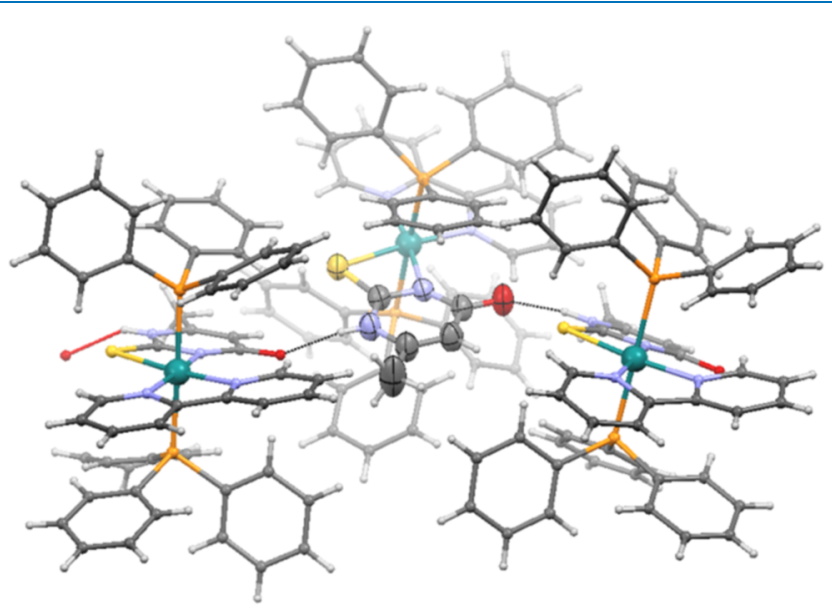

Figure 2. H-bonds forming an infinite $\mathrm{N}-\mathrm{H} \cdots \mathrm{O}$ chain.

The structural aspects of complexes $\mathbf{1}$ and $\mathbf{2}$ may contribute to affecting their biological activity. In the CT-DNA binding study, by UV absorption titration, it was found that the intrinsic binding constant $\left(K_{\mathrm{b}}\right)$ values around 3.0-5.0 $\times 10^{3}$ $\mathrm{M}^{-1}$. These results suggested that complexes 1 and 2 interact weakly with DNA, compared with others complexes with thiouracil derivatives, as previously reported, which present more regions capable of carrying out hydrogen bonds, showing $K_{\mathrm{b}}$ constants at around $10^{4} \mathrm{M}^{-1}$. ${ }^{17}$ Furthermore, the $K_{\mathrm{b}}$ values found are lower than those for complexes, which demonstrates the ability to intercalate DNA. ${ }^{29,30}$

The cytotoxicity activities of compounds $\mathbf{1}$ and $\mathbf{2}$ were investigated against four cancer cells and one noncancer cell population (Table 1). Even though the $\mathrm{IC}_{50}$ values are similar for both compounds, complex $\mathbf{2}$ was more potent cytotoxic than complex 1 . Both complexes showed $\mathrm{IC}_{50}$ values for cancer cells comparable with the platinum metallodrug, oxaliplatin, 
Table 1. $\mathrm{IC}_{50}$ Values $(\mu \mathrm{M})$ Obtained from the Cytotoxicity Assay and DNA Binding Constant $\left(K_{\mathrm{b}}\right)$ for Complexes 1 and $2^{a}$

\begin{tabular}{|c|c|c|c|c|c|}
\hline \multirow[b]{2}{*}{ cells } & \multirow[b]{2}{*}{ hystotype } & \multicolumn{4}{|c|}{$\mathrm{IC}_{50}$ in $\mu \mathrm{M}$} \\
\hline & & 1 & 2 & oxaliplatin & doxorubicin \\
\hline \multicolumn{6}{|c|}{ cancer cells } \\
\hline \multirow[t]{2}{*}{ HL-60 } & human promyelocytic leukemia & 2.33 & 1.65 & 0.45 & 0.09 \\
\hline & & $1.38-3.94$ & $1.09-2.48$ & $0.34-1.06$ & $0.04-0.15$ \\
\hline \multirow[t]{2}{*}{ K-562 } & human chronic myelocytic leukemia & 2.75 & 2.12 & 1.30 & 0.15 \\
\hline & & $1.88-4.05$ & $1.40-3.20$ & $0.46-2.12$ & $0.05-0.23$ \\
\hline \multirow[t]{2}{*}{ HepG2 } & human hepatocellular carcinoma & 12.31 & 9.13 & 1.00 & 0.02 \\
\hline & & $8.10-18.71$ & $6.86-12.14$ & $0.36-2.25$ & $0.01-0.05$ \\
\hline \multirow[t]{2}{*}{ B16-F10 } & melanoma & 5.28 & 3.07 & 0.07 & 0.02 \\
\hline & & $3.55-7.84$ & $2.09-4.52$ & $0.04-0.09$ & $0.01-0.06$ \\
\hline \multicolumn{6}{|c|}{ noncancer cells } \\
\hline \multirow[t]{2}{*}{ PBMC } & human peripheral blood mononuclear cells & 6.99 & 3.91 & 8.45 & 2.45 \\
\hline & & $3.68-13.25$ & $2.26-6.78$ & $4.53-13.47$ & $1.35-4.45$ \\
\hline \multicolumn{6}{|c|}{ DNA binding constant } \\
\hline$K_{\mathrm{b}}\left(10^{3} \mathrm{M}^{-1}\right)$ & & $5.0 \pm 1.1$ & $3.0 \pm 1.0$ & & \\
\hline
\end{tabular}

${ }^{a} \mathrm{IC}_{50}(\mu \mathrm{M})$ were obtained by nonlinear regression from three independent experiments that were executed in duplicate, using Alamar blue assay after $72 \mathrm{~h}$ incubation. DNA binding constants are presented as mean \pm S.D.

and doxorubicin (see Table 1). The free ligands $2 \mathrm{TU}$ and $6 \mathrm{~m} 2 \mathrm{TU}$ were not cytotoxic at the concentrations investigated.

As shown in Table 2, complexes 1 and 2 presented more selectivity to HL-60 (3 times more cytotoxicity in relation to

Table 2. Selectivity Index (SI) of Complexes 1 and $2^{a}$

\begin{tabular}{lcccc} 
& \multicolumn{4}{c}{ noncancer cell } \\
\cline { 2 - 5 } & \multicolumn{4}{c}{ PBMC } \\
\cline { 2 - 5 } cancer cells & 1 & 2 & OXA & DOX \\
HL-60 & 3.0 & 2.37 & 18.78 & 27.22 \\
K-562 & 2.5 & 1.84 & 6.5 & 16.33 \\
HepG2 & 0.57 & 0.43 & 8.45 & 122.5 \\
B16-F10 & 1.32 & 1.27 & 120.7 & 122.5
\end{tabular}

${ }^{a}$ Selectivity index (SI) of complexes was determined by the relation of $\mathrm{IC}_{50}$ values: $\mathrm{SI}=\mathrm{IC}_{50}$ [noncancer cells $] / \mathrm{IC}_{50}$ [cancer cells]. Cancer cells: HL-60 (human acute promyelocytic leukemia); K-562 (human chronic myelogenous leukemia); HepG2 (human hepatocellular carcinoma); and B16-F10 (mouse melanoma). Noncancer cells: PBMC (human peripheral blood mononuclear cells). Doxorubicin (DOX) and oxaliplatin (OXA) were used as positive controls.

PBMC for complex 1 and 2.37 times more cytotoxicity in relation to $\mathrm{PBMC}$ for complex 2) when compared with the other cancer cells (K562, HepG2, and B16-F10).

Next, we examined light-scattering features, annexin $\mathrm{V}$ FITC/PI staining, and intracellular DNA content of HL-60 cells after incubation with complexes 1 ( 1 and $2 \mu \mathrm{M})$ and 2 $(0.5$ and $1 \mu \mathrm{M})$ by flow cytometry. Both complexes caused cell shrinkage, as observed by reduction in forward light scatter (FSC), and nuclear condensation, as observed by increase in side scatter (SCC), both morphological changes characteristic of apoptotic cells (Figure 3). In addition, augments in the percentage of early apoptotic cells was found in HL-60 cells treated with both complexes $(P<0.05)$ (Figure 4$)$. Complex 1 induced early apoptotic cells in 40.5 and $49.8 \%$, while 36.5 and $41.7 \%$ were found after the treatment with complex 2 at the lowest and highest concentrations, respectively. Doxorubicin $(1 \mu \mathrm{M})$ caused early apoptotic cells in $35.4 \%$ against $8.1 \%$ observed in the negative control. Both complexes also caused a significant internucleosomal DNA fragmentation in HL-60 cells after $24 \mathrm{~h}$ incubation $(P<0.05)$ (Figure 5). Complex 1 increased the DNA fragmentation to 71.4 and $94.0 \%$ and complex 2 increased it to 47.2 and $67.9 \%$, at lowest and highest concentrations, respectively. Doxorubicin $(1 \mu \mathrm{M})$ increased the DNA fragmentation up to $59.7 \%$, and $18.6 \%$ was observed for negative control cells. The cell cycle phases, $G_{1} / G_{0}, S$, and $\mathrm{G}_{2} / \mathrm{M}$, were reduced proportionally.

\section{CONCLUSIONS}

In summary, two new $\mathrm{Ru}(\mathrm{II})$ complexes [1 and 2] containing thiouracil derivatives were synthetized and studied against cancer cells. Complexes $\mathbf{1}$ and $\mathbf{2}$ are cationic, presenting the two triphenylphosphine ligands in the trans configuration to each other, such as suggested by the ${ }^{31} \mathrm{P}\left\{{ }^{1} \mathrm{H}\right\}$ NMR experiments. The thiouracil ligand presents the sulfur atom and $\mathrm{N} 3$ atom trans to $\mathrm{N} 4$ and N2 nitrogen of bipyridine, respectively. The complex/DNA binding studied reveals the $K_{\mathrm{b}}$ of about $10^{3} \mathrm{M}^{-1}$, revealing a weak DNA interaction. The $\mathrm{IC}_{50}$ values against cancer cells for complexes $\mathbf{1}$ and $\mathbf{2}$ are lower than the $\mathrm{IC}_{50}$ values against noncancer cells that are desired. The complex 2 with $6 \mathrm{~m} 2 \mathrm{TU}$ ligand showed a higher potency than the complex 1 with $2 \mathrm{TU}$ ligand. Both $\mathrm{Ru}(\mathrm{II})$ compounds caused DNA fragmentation, leading cell death by apoptosis. Complexes $\mathbf{1}$ and $\mathbf{2}$ also altered the cell cycle, reducing the cells in $G_{1} / G_{0}, S$, and $G_{2} / M$ phases.

\section{EXPERIMENTAL SECTION}

Synthesis of the Complexes. Synthesis of trans$\left[R u(2 T U)\left(P P h_{3}\right)_{2}\right.$ (bipy)]PF 6 (1) and trans-[Ru(6m2TU)$\left(P P h_{3}\right)_{2}$ (bipy)]PF 6 (2). To the reactional media, $0.19 \mathrm{mmol}$ of $2 \mathrm{TU}(24 \mathrm{mg})$ or $6 \mathrm{~m} 2 \mathrm{TU}(27 \mathrm{mg})$ ligands, in methanol (20 $\mathrm{mL}$ ), and with $20 \mu \mathrm{L}$ of triethylamine was added using a Schlenk flask. After ligand solubilization, $150 \mathrm{mg}(0.18 \mathrm{mmol})$ of the complex precursor, $\left[\mathrm{RuCl}_{2}\left(\mathrm{PPh}_{3}\right)_{2}\right.$ (bipy)], dissolved in $80 \mathrm{~mL}$ of $\mathrm{CH}_{2} \mathrm{Cl}_{2}$ solvent was added to the Schlenk flask. The reactional systems were kept under reflux and stirring for about $12 \mathrm{~h}$. After that, the volume of the solution was reduced to ca. $2 \mathrm{~mL}$, and the orange solid was precipitated by water. The final products 1 and $\mathbf{2}$ were collected by filtration, washed with hot water, diethyl ether, and dried under vacuum. Yield $135 \mathrm{mg}$ (73\%) for compound 1 and $150 \mathrm{mg}$ (80\%) for compound 2. 


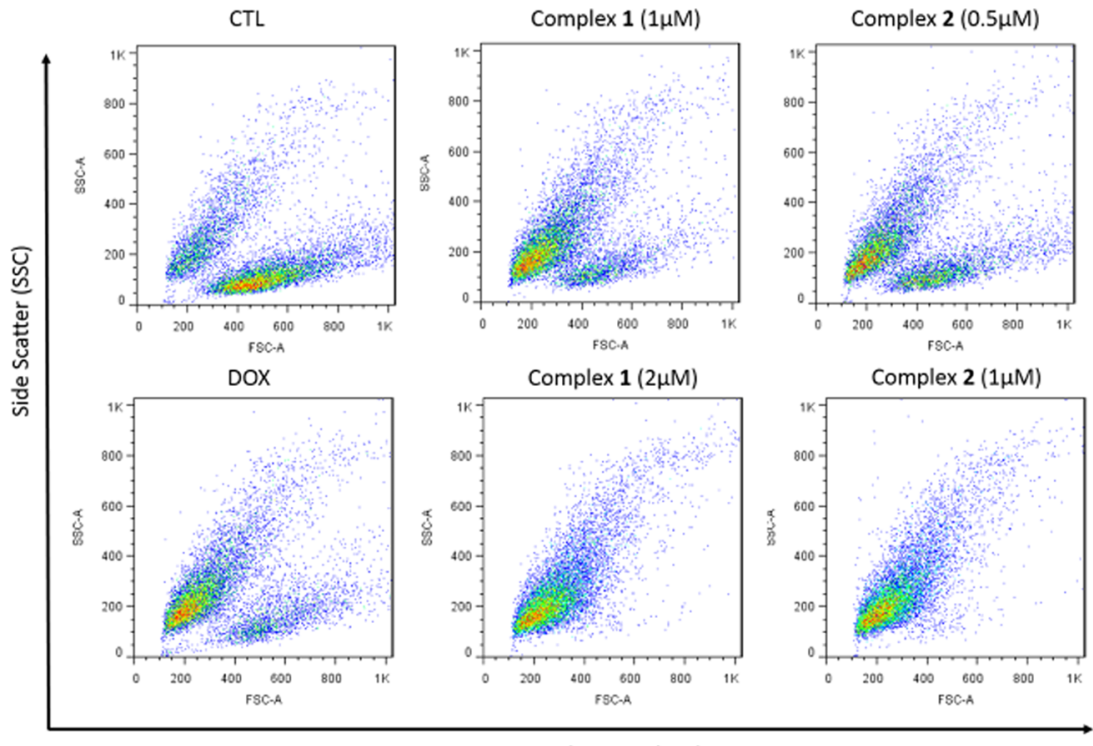

Forward Scatter (FSC)

Figure 3. Effect of complexes $\mathbf{1}$ and $\mathbf{2}$ in HL-60 cell morphology, as determined by light-scattering features detected by flow cytometry after $24 \mathrm{~h}$ incubation. Negative control (CTL) was treated with vehicle (0.1\% DMSO), and doxorubicin (DOX, $1 \mu \mathrm{M})$ was used as a positive control. Data are presented as representative flow cytometric dot plots of three independent experiments performed in duplicate. Ten thousand events were evaluated per experiment, and cellular debris omitted from analysis.

Complex 1. Molar conductance $\left(\Omega^{-1} \mathrm{~cm}^{2} \mathrm{~mol}^{-1}, \mathrm{CH}_{2} \mathrm{Cl}_{2}\right)$ 50.1. Anal. calcd for $\left[\mathrm{RuC}_{50} \mathrm{H}_{41} \mathrm{~F}_{6} \mathrm{~N}_{4} \mathrm{OSP}_{3}\right]$ : exp. (calcd) C 56.68(56.87); H 4.37(4.10), N 5.23(5.31); S 2.78(3.04) \%. IR $\left(\mathrm{cm}^{-1}\right): 3202,3115,3078,3057,2957,2924,2854,1657$, $1636,1605,1585,1539,1481,1433,1275,1190,1159,1090$, 1026, 1001, 841, 760, 744, 717, 696, 619, 557, 519, 403, 353. ${ }^{31} \mathrm{P}\left\{{ }^{1} \mathrm{H}\right\}$ NMR (162 MHz, DMSO-d $\left.d_{6}, 298 \mathrm{~K}\right) \delta(\mathrm{ppm}): 32.165$ (s); ${ }^{1} \mathrm{H}$ NMR (400 MHz, DMSO- $\left.d_{6}, 298 \mathrm{~K}\right) \delta(\mathrm{ppm}): 12.16$ $(\mathrm{H}, \mathrm{N}-\mathrm{H}$ of $2 \mathrm{TU}) ; 11.49$ and $10.64(2 \mathrm{H}, \mathrm{C}-\mathrm{H}$ of bipy near the coordinated nitrogen atoms); $8.00-7.50(6 \mathrm{H}$ atoms of bipy) $6.7\left(\mathrm{H}, \mathrm{C}_{6}-\mathrm{H}\right.$ of $\left.2 \mathrm{TU}\right) ; 5.2\left(\mathrm{H}, \mathrm{C}_{5}-\mathrm{H}\right.$ of $\left.2 \mathrm{TU}\right)$. ${ }^{13} \mathrm{C}\left\{{ }^{1} \mathrm{H}\right\}$ NMR $\left(125.74 \mathrm{MHz}\right.$, DMSO- $\left.d_{6}, 298 \mathrm{~K}\right) \delta(\mathrm{ppm})$ : $176.5(\mathrm{C}=\mathrm{S}) ; 171.5(\mathrm{C}=\mathrm{O}) ; 156.2(\mathrm{C} 6$ of $2 \mathrm{TU}), 106.2(\mathrm{C} 5$ of 2TU); 158.20-157.56, 137.0-122.3 (C-bipy, C- $\mathrm{PPh}_{3}$ ). UV-vis (DMSO, $\left.5 \times 10^{-5} \mathrm{M}\right): \lambda / \mathrm{nm}\left(\varepsilon / \mathrm{M}^{-1} \mathrm{~cm}^{-1}\right) 300$ (30 000), 336 (15 500), 450 (6000).

Complex 2. Molar conductance $\left(\Omega^{-1} \mathrm{~cm}^{2} \mathrm{~mol}^{-1}, \mathrm{CH}_{2} \mathrm{Cl}_{2}\right)$ 58.4. Anal. calcd for $\left[\mathrm{RuC}_{51} \mathrm{H}_{43} \mathrm{~F}_{6} \mathrm{~N}_{4} \mathrm{OSP}_{3}\right]$ : exp. (calcd): $\mathrm{C}$ 57.55(57.25), H 4.60(4.24), N 5.33(5.24), S 2.89(3.00) \%. IR $\left(\mathrm{cm}^{-1}\right)$ 3207, 3117, 3076, 3057, 2958, 2924, 2854, 2795, 1651, $1618,1605,1572,1537,1481,1433,1470,1365,1309,1273$, 1221, 1184, 1159, 1090, 1072, 1028, 999, 843, 764, 744, 698, $613,557,519,403,351 .{ }^{31} \mathrm{P}\{1 \mathrm{H}\}$ NMR $\left(162 \mathrm{MHz}\right.$, DMSO-d $d_{6}$, $298 \mathrm{~K}): \delta(\mathrm{ppm}) 32.161(\mathrm{~s}) ;{ }^{1} \mathrm{H}$ NMR $\left(400 \mathrm{MHz}\right.$, DMSO- $d_{6}$, $298 \mathrm{~K}) \delta(\mathrm{ppm}): 11.3(\mathrm{H}, \mathrm{N}-\mathrm{H}), 10.6$ and $9.2(2 \mathrm{H}, \mathrm{C}-\mathrm{H}$ of bipy near the coordinated nitrogen atoms); $8.00-7.00(30 \mathrm{H}$ of $\mathrm{PPh}_{3}$ ligands and $6 \mathrm{H}$ aromatic hydrogen atoms of bipy); 5.05 $\left(\mathrm{H}, \mathrm{C}_{5}-\mathrm{H}\right.$ of $\left.6 \mathrm{~m} 2 \mathrm{TU}\right) ; 1.6\left(3 \mathrm{H}, \mathrm{CH}_{3}\right.$ of $\left.6 \mathrm{~m} 2 \mathrm{TU}\right) .{ }^{13} \mathrm{C}\left\{{ }^{1} \mathrm{H}\right\}$ NMR $\left(125.74 \mathrm{MHz}\right.$, DMSO-d $\left.d_{6}, 298 \mathrm{~K}\right) \delta(\mathrm{ppm}): 176.1(\mathrm{C}=$ S); $171.4(\mathrm{C}=\mathrm{O}) ; 158.4-122.2(1 \mathrm{C}$ at position 6 of $6 \mathrm{~m} 2 \mathrm{TU}$, 10C of bipy, 36C of $\mathrm{PPh}_{3}$ ligands), 105.2 (1C at position 5 of $6 \mathrm{~m} 2 \mathrm{TU}), 16.6$ (1C of the methyl group of $6 \mathrm{~m} 2 \mathrm{TU})$. UV-vis (DMSO, $\left.1.8 \times 10^{-5} \mathrm{M}\right): \lambda / \mathrm{nm}\left(\varepsilon / \mathrm{M}^{-1} \mathrm{~cm}^{-1}\right) 300(34000)$, 338 (13 100), 452 (7010).

Physical Measurements and Materials. The commercial reagents were of grade or comparable purity and used as supplied. The compounds used here, CT-DNA, Tris-HCl,
Tris-base, oxaliplatin, $\mathrm{PPh}_{3}$, bipy, $2 \mathrm{TU}, 6 \mathrm{~m} 2 \mathrm{TU}$, and $\mathrm{RuCl}_{3}$. $3 \mathrm{H}_{2} \mathrm{O}$, were acquired from Sigma-Aldrich (St. Louis, MO). Elementary analyses were carried out on an EA 1108 FISONS Instruments CHNS microanalyzer. High-resolution mass spectra (HRMS) of complexes $\mathbf{1}$ and $\mathbf{2}$ were obtained in a MicroTof-Q II Bruker Daltonics Mass Spectrometer (Le) in the positive-ion mode, using methanol/acetonitrile as solvents (LC/MS grade from Honeywell/B\&J Brand). Conductivity values were determined using $10^{-3} \mathrm{M}$ solutions of the complexes in $\mathrm{CH}_{2} \mathrm{Cl}_{2}$ employing a MeterLab CDM2300 instrument. In addition, the IR spectra were obtained, in CsI, on a FT-IR Bomem-Michelson 102 spectrometer in the 4000$200 \mathrm{~cm}^{-1}$ region. Cyclic voltammetry (CV) experiments were carried out using an electrochemical analyzer BAS, model 100B at room temperature. For that, an $\mathrm{CH}_{2} \mathrm{Cl}_{2}$ solution containing $0.10 \mathrm{~mol} \mathrm{~L}^{-1} \mathrm{Bu}_{4} \mathrm{NClO}_{4}$ (TBAP) as a supporting electrolyte was employed and an one-compartment cell, with both working and auxiliary electrodes as stationary $\mathrm{Pt}$ foils, and $\mathrm{Ag} / \mathrm{AgCl}$ as the reference electrode, $0.10 \mathrm{M}$ TBAP in $\mathrm{CH}_{2} \mathrm{Cl}_{2}$, was employed. Under these conditions, the ferrocene $(\mathrm{Fc})$ is oxidized at $0.43 \mathrm{~V}\left(\mathrm{Fc}_{\mathrm{c}} / \mathrm{Fc}_{\mathrm{c}}\right)$. All complexes were studied by NMR technique $\left({ }^{1} \mathrm{H},{ }^{31} \mathrm{P}\left\{{ }^{1} \mathrm{H}\right\}\right.$, and ${ }^{13} \mathrm{C}$ NMR). All spectra were obtained on a Bruker DRX $400 \mathrm{MHz}$, using tetramethylsilane (TMS) as an internal reference and solvent DMSO- $d_{6}$ to the two compounds. The ${ }^{31} \mathrm{P}\left\{{ }^{1} \mathrm{H}\right\}$ chemical shifts were reported based on $\mathrm{H}_{3} \mathrm{PO}_{4} 85 \%$ reference. All of the spectra obtained here are represented in the Supporting Information (Figures S1-S25). The UV-vis spectra of complexes $\mathbf{1}$ and 2 were obtained on a Hewlett Packard diode array $8452 \mathrm{~A}$, using $\mathrm{CH}_{2} \mathrm{Cl}_{2}$ as a solvent. All single crystals of the $\mathrm{Ru}(\mathrm{II})$-thiouracil-based complexes (1 and 2) were obtained at room temperature by the solvent diffusion method. We have used the diffusion of diethyl ether to a complex solution $\left(\mathrm{CH}_{2} \mathrm{Cl}_{2} / \mathrm{CH}_{3} \mathrm{OH}\right)$. Single-crystal X-ray diffraction experiments for both complexes were carried out at room temperature on an Enraf-Nonius Kappa-CCD diffractometer using the Mo $\mathrm{K} \alpha$ radiation $(\lambda=0.71073 \AA)$ 

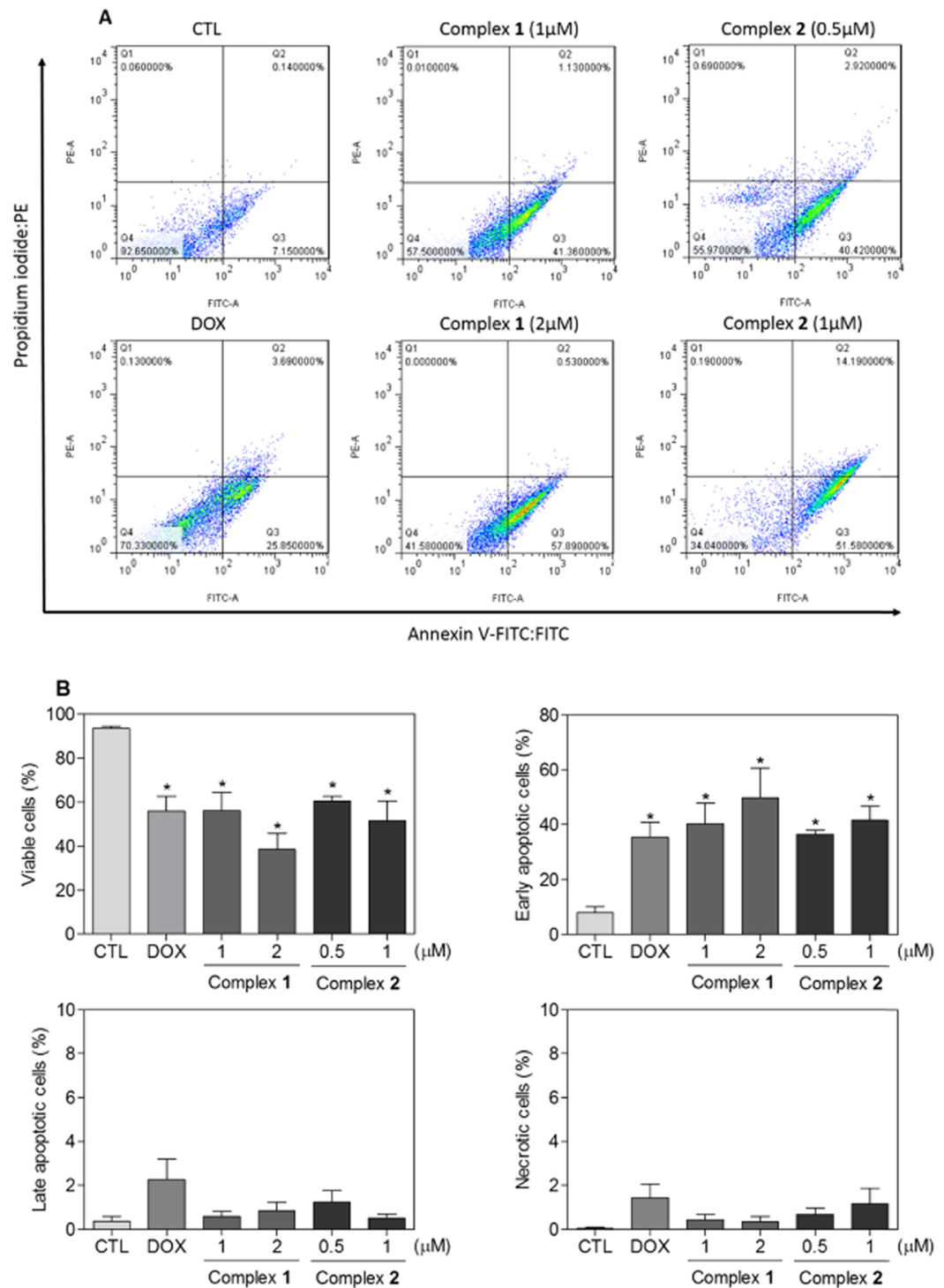

Figure 4. Effect of complexes 1 and 2 on apoptosis induction in HL-60 cells, as determined by flow cytometry using annexin V-FITC/propidium iodide staining after $24 \mathrm{~h}$ incubation. (A) Representative flow cytometric dot plots. (B) Quantification of viable (annexin V-FITC/PI double negative cells), early apoptosis (annexin V-FITC positive, but PI negative cells), late apoptosis (annexin V-FITC/PI double positive cells), and necrosis cells (PI positive, but annexin V-FITC negative cells). Negative control (CTL) was treated with vehicle (0.1\% DMSO), and doxorubicin $(\mathrm{DOX}, 1 \mu \mathrm{M})$ was used as positive control. Data are presented as mean \pm S.E.M. of three independent experiments performed in duplicate. Ten thousand events were evaluated per experiment, and cellular debris omitted from analysis. $* P<0.05$ compared with negative control by ANOVA, followed by Student-Newman-Keuls test.

monochromated by graphite. The crystal structures of $\mathbf{1}$ and $\mathbf{2}$ were solved by the direct method and refined using the SHELXS-97 and SHELXL-97 programs, respectively. Absorption corrections were carried out using the Gaussian method. All nonhydrogen atoms of complexes $\mathbf{1}$ and $\mathbf{2}$ were located and refined with anisotropic thermal parameters. The $\mathrm{C}-\mathrm{H}$ aromatic hydrogen atoms were added with $\mathrm{C}-\mathrm{H}$ distance fixed at $0.93 \AA$ and refined with fixed displacement parameters $\left[U_{\text {iso }}(\mathrm{H})=1.2 U_{\text {eq }}\left(\mathrm{Csp}^{2}\right)\right]$. In complex 2, the H-atoms of the methyl group were set as isotropic with the $\mathrm{C}-\mathrm{H}$ distance of $0.96 \AA$ and $U_{\text {iso }}(\mathrm{H})=1.5 U_{\text {eq }}\left(\mathrm{Csp}^{3}\right)$.

For structure representations, the MERCURY 4.0 program was used. In addition, we have used the CrystalExplorer program to access the Hirshfeld surfaces, allowing us to obtain the fingerprint plots for complexes $\mathbf{1}$ and 2.

CT-DNA Binding Experiments. Spectroscopic Titrations. To study the DNA interaction by spectroscopic titrations, we have used a DNA solution prepared in a Tris- $\mathrm{HCl}$ buffer at $\mathrm{pH}=7.2[0.5 \mathrm{mM}$ Tris-base, $5 \mathrm{mM}$ Tris- $\mathrm{HCl}, 50 \mathrm{mM} \mathrm{NaCl}]$. The ration of UV absorbance at 260 and $280 \mathrm{~nm}$ indicated that the CT-DNA solution is protein-free. Thus, the concentration of CT-DNA was determined using the absorption intensity at $260 \mathrm{~nm}$ and the molar absorption coefficient value of 6600 $\mathrm{M}^{-1} \mathrm{~cm}^{-1}$. The ruthenium complexes 1 and 2 were solubilized in a Tris- $\mathrm{HCl}$ buffer containing DMSO at 5\%. The UV-vis titration experiments were performed keeping the concentration of ruthenium complex fixed at $25 \mu \mathrm{M}$ and increasing the concentrations of the CT-DNA. A sample correction was made for the absorbance of DNA and the spectra were recorded after solution equilibration for $2 \mathrm{~min}$. The intrinsic equilibrium binding constant $\left(K_{\mathrm{b}}\right)$ of the complexes to CTDNA was obtained using the expression of Wolfe and coworkers. $^{31}$ Alterations in the absorption intensity with the 

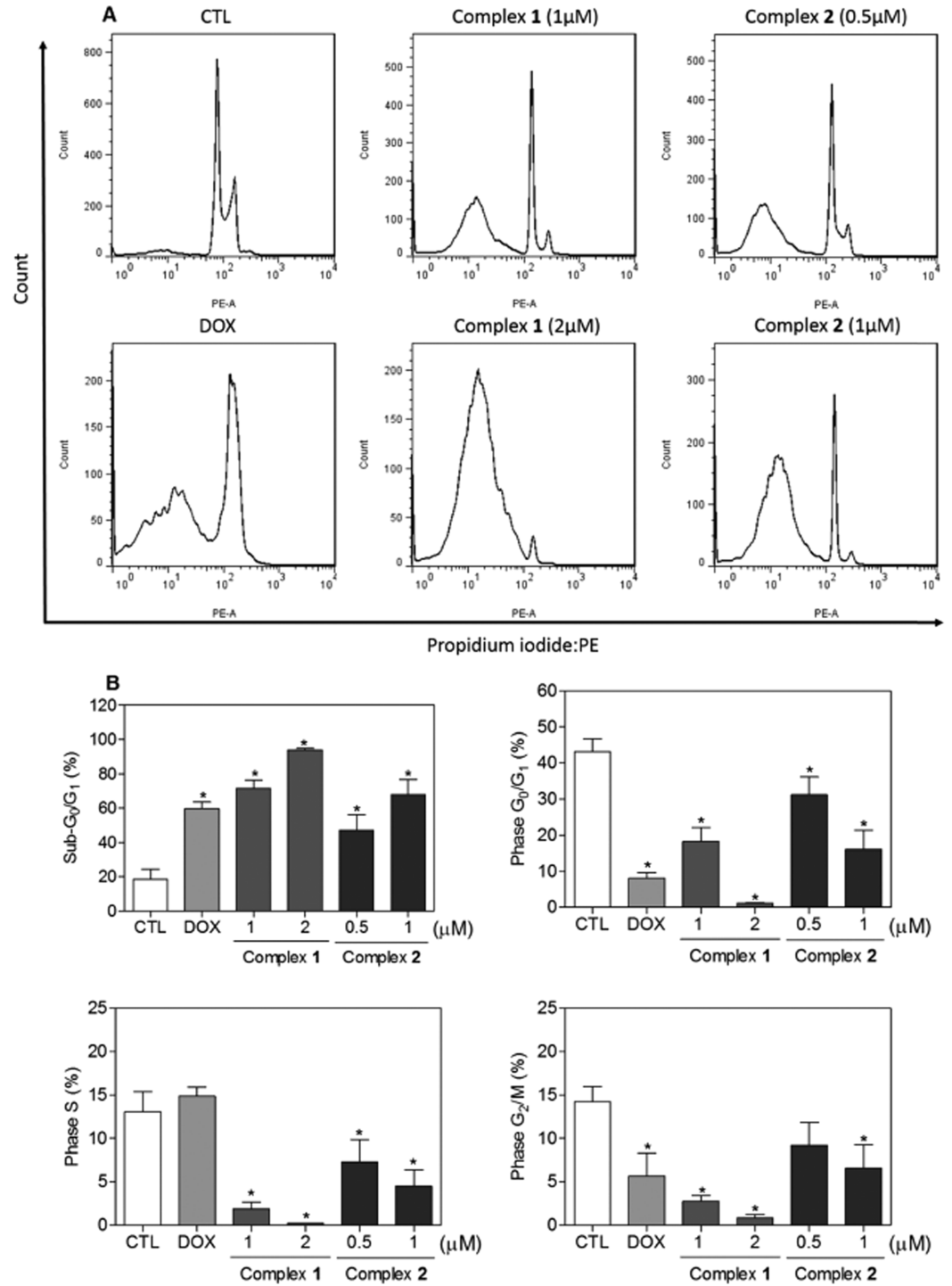

Figure 5. Effect of complexes 1 and $\mathbf{2}$ in the cell cycle distribution of HL-60 cells, as determined by flow cytometry using propidium iodide staining after $24 \mathrm{~h}$ incubation. (A) Representative flow cytometric histograms. (B) Quantification of sub- $\mathrm{G}_{1}$ (internucleosomal DNA fragmentation), $\mathrm{G}_{0} /$ $\mathrm{G}_{1}, \mathrm{~S}$, and $\mathrm{G}_{2} / \mathrm{M}$ percentage distribution. Negative control (CTL) was treated with vehicle (0.1\% DMSO), and doxorubicin (DOX, $\left.1 \mu \mathrm{M}\right)$ was used as a positive control. Data are presented as mean \pm S.E.M. of three independent experiments performed in duplicate. Ten thousand events were evaluated per experiment, and cellular debris omitted from analysis. $* P<0.05$ compared with negative control by ANOVA, followed by the Student-Newman-Keuls test.

increasing concentration of CT-DNA was monitored and analyzed by regression analysis.

In Vitro Cytotoxicity Assay. HL-60 (human promyelocytic leukemia), K-562 (human chronic myelocytic leukemia), HepG2 (human hepatocellular carcinoma), and B16-F10 (mouse melanoma) cell lines were obtained from American Type Culture Collection (ATCC, Manassas, VA) and cultured following the instructions of ATCC animal cell culture guide. All cell lines were tested for mycoplasma by Lookout Mycoplasma qPCR detection kit (Sigma-Aldrich) and were mycoplasma free. Peripheral blood mononuclear cells (PBMCs) were isolated by Ficoll density gradient in GE Ficoll-Paque Plus from heparinized blood collected from 20- to 35-year-old, nonsmoker healthy donors after obtaining an informed consent. PBMCs were cultured in RPMI 1640 medium plus $20 \%$ fetal bovine serum, $2 \mathrm{mM}$ glutamine, and 50 $\mu \mathrm{g} / \mathrm{mL}$ gentamycin at $37{ }^{\circ} \mathrm{C}$ with $5 \% \mathrm{CO}_{2}$. ConA $(10 \mu \mathrm{g} / \mathrm{mL})$ was added at the beginning of the culture and treated with complexes $\mathbf{1}$ and $\mathbf{2}$ after $24 \mathrm{~h}$ incubation. Research Ethics Committee from the Fiocruz-BA approved the experimental protocol (number 031019/2013).

Cell viability was measured by alamar blue method, as previously described. ${ }^{32}$ Cells were plated into 96-well plates $\left(0.7 \times 10^{5}\right.$ cells $/ \mathrm{mL}$ for adherent cells or $0.3 \times 10^{6}$ cells $/ \mathrm{mL}$ for cells suspended in $100 \mu \mathrm{L}$ of medium). After $24 \mathrm{~h}$, complexes $\mathbf{1}$ and $\mathbf{2}$ were dissolved in DMSO to form a solution of $0.19-25.0 \mu \mathrm{g} / \mathrm{mL}$. Then, the sample compounds were added to each well and kept incubated for a period of $72 \mathrm{~h}$. Oxaliplatin (OXA) and DOX, doxorubicin hydrochloride, from Laboratory IMA S.A.I.C were used as positive controls. Four hours (for cell lines) or $24 \mathrm{~h}$ (for PBMC) before the end of incubation, $20 \mu \mathrm{L}$ of a stock solution $(0.312 \mathrm{mg} / \mathrm{mL})$ of alamar blue (resazurin; from Sigma-Aldrich) was added to each well. Absorbance was measured using a SpectraMax 190 multiplate reader at 570 and $600 \mathrm{~nm}$. 
Flow Cytometric Assays. FITC Annexin V apoptosis detection kit I (BD Biosciences, San Jose, CA) was used for apoptosis quantification, and the analysis was performed according to manufacturer's instructions. Cell fluorescence and light scattering features were measured by flow cytometry. Percentages of viable (annexin V-FITC/PI double negative cells), early apoptotic (annexin V-FITC positive, but PI negative cells), late apoptotic (annexin V-FITC/PI double positive cells), and necrotic (PI positive, but annexin V-FITC negative cells) cells were quantified.

Internucleosomal DNA fragmentation and cell cycle distribution were analyzed by the quantification of DNA content. ${ }^{33}$ Cells were harvested in a permeabilization solution containing $0.1 \%$ Triton $\mathrm{X}-100,2 \mu \mathrm{g} / \mathrm{mL}$ propidium iodide (PI), $0.1 \%$ sodium citrate, and $100 \mu \mathrm{g} / \mathrm{mL}$ RNAse (all from Sigma-Aldrich Co.) and incubated in dark for $15 \mathrm{~min}$ at room temperature. Cell fluorescence was determined by flow cytometry. In this assay, all DNA sub-diploid in size (sub$\mathrm{G}_{1} / \mathrm{G}_{0}$ ) was considered internucleosomal DNA fragmentation, and $G_{1} / G_{0}, S$, and $G_{2} / M$ phases were quantified.

For all flow cytometry analyses, 10000 events were recorded per sample using a BD LSRFortessa cytometer, BD FACSDiva software (BD Biosciences), and FlowJo software 10 (FlowJo Lcc; Ashland, OR). Cellular debris were omitted from the analysis.

Statistical Analysis. Data are presented as mean \pm S.E.M. or $\mathrm{IC}_{50}$ values [half-maximal inhibitory concentration], and their $95 \%$ confidence intervals calculated by nonlinear regression from three independent experiments evaluated in duplicate. Statistical analysis was carried out using the Intuitive Software for Science GRAPHPAD.

\section{ASSOCIATED CONTENT}

\section{S Supporting Information}

The Supporting Information is available free of charge at https://pubs.acs.org/doi/10.1021/acsomega.9b01921.

Crystallographic information files (CIFs) were deposited on the Cambridge Structural database [CCDC 1924442 (1) and CCDC 1924443 (2)]. These data can be obtained free of charge via http://www.ccdc.cam.ac.uk/ conts/retrieving.html (or from the CCDC, 12 Union Road, Cambridge CB2 1EZ, U.K.; Fax: +44 1223 336033; E-mail: deposit@ccdc.cam.ac.uk); Figures S1S6 $\left({ }^{31} \mathrm{P}\left\{{ }^{1} \mathrm{H}\right\},{ }^{13} \mathrm{C}\left\{{ }^{1} \mathrm{H}\right\}\right.$, and ${ }^{1} \mathrm{H}$ NMR spectra for complexes 1 and 2); Figure $S 7{ }^{1} \mathrm{H}-{ }^{1} \mathrm{H}$ COSY of complex 1; Figure S8 and S9 (HRMS spectra for complexes 1 and 2), S10 and S11 (IR spectra for compounds 1 and 2), S12 and S13 (electrochemical experiment for compounds 1 and 2), S14 (Hirshfeld surface and fingerprint plot for compounds 1 and 2), S15 (CT-DNA titration for compounds 1 and 2), S16 and S17 (UV-vis spectra in DMSO for complexes 1 and 2), S18 $\left({ }^{31} \mathrm{P}\left\{{ }^{1} \mathrm{H}\right\}\right.$ NMR spectra of complex 1 and complex 2 after 24 h of incubation in DMSO), and S19 $\left({ }^{1} \mathrm{H}\right.$ NMR signal integrations for complexes 1 and 2$)$; Table S1 (X-ray data collections and refinement details for complexes 1 and 2); Table S2 (Infrared assignment for complexes 1 and 2) (PDF)

\section{AUTHOR INFORMATION}

\section{Corresponding Author}

*E-mail: rodrigocorrea@ufop.edu.br.

\section{ORCID}

Daniel P. Bezerra: 0000-0002-6774-2063

Rodrigo S. Correa: 0000-0003-2783-0816

\section{Author Contributions}

"D.E.L.C. and K.M.O. contributed equally. The manuscript was written through contributions of all of the authors. All of the authors have given approval to the final version of the manuscript.

Notes

The authors declare no competing financial interest.

\section{ACKNOWLEDGMENTS}

The authors would like to thank the financial support of Brazilian Research Agencies: FAPEMIG, FAPESB, FAPESP, $\mathrm{CNPq}$ and CAPES. D.E.L.C. thanks FAPEMIG for a fellowship, and K.M.O. is supported by a postdoctoral fellowship grant from CAPES (PNPD program). Also, R.S.C. would like to thank the financial support provided by PROPP/ UFOP, FAPEMIG (APQ-01674-18), and CNPq (grants 403588/2016-2 and 308370/2017-1). The authors thank the IFSC-USP (E.E. Castellano and J.A. Ellena) for X-ray crystallography measurements and the "Laboratório Multiusuário de Caracterização de Moléculas”/UFOP for the NMR facilities.

\section{REFERENCES}

(1) Goodgame, M.; Jakubovic, D. A. Metal Complexes of Uracils. Coord. Chem. Rev. 1987, 79, 97-134.

(2) Rios, A. C.; Tor, Y. On the Origin of the Canonical Nucleobases: An Assessment of Selection Pressures across Chemical and Early Biological Evolution. Isr. J. Chem. 2013, 53, 469-483.

(3) Bhagavan, N. V.; Ha, C.-E. Chapter 25 - Nucleotide Metabolism. In Essentials of Medical Biochemistry, 2nd ed.; Bhagavan, N. V.; Ha, C.E., Eds.; Academic Press: San Diego, 2015; pp 465-487.

(4) Scofield, M. Nucleic Acids. In xPharm: The Comprehensive Pharmacology Reference; Enna, S. J.; Bylund, D. B., Eds.; Elsevier: New York, 2007; pp 1-15.

(5) Miura, K.; Kinouchi, M.; Ishida, K.; Fujibuchi, W.; Naitoh, T.; Ogawa, H.; Ando, T.; Yazaki, N.; Watanabe, K.; Haneda, S.; et al. 5FU Metabolism in Cancer and Orally-Administrable 5-FU Drugs. Cancers 2010, 2, 1717-1730.

(6) Giacchetti, S.; Perpoint, B.; Zidani, R.; Le Bail, N.; Faggiuolo, R.; Focan, C.; Chollet, P.; Llory, J. F.; Letourneau, Y.; Coudert, B.; et al. Phase III Multicenter Randomized Trial of Oxaliplatin Added to Chronomodulated Fluorouracil-Leucovorin as First-Line Treatment of Metastatic Colorectal Cancer. J. Clin. Oncol. 2000, 18, 136.

(7) Nunes, J. H. B.; Bergamini, F. R. G.; Lustri, W. R.; de Paiva, P. P.; Ruiz, A. L. T. G.; de Carvalho, J. E.; Corbi, P. P. Synthesis, Characterization and in Vitro Biological Assays of a Silver(I) Complex with 5-Fluorouracil: A Strategy to Overcome Multidrug Resistant Tumor Cells. J. Fluorine Chem. 2017, 195, 93-101.

(8) Silva, V. R.; Corrêa, R. S.; de Souza Santos, L.; Soares, M. B. P.; Batista, A. A.; Bezerra, D. P. A Ruthenium-Based 5-Fluorouracil Complex with Enhanced Cytotoxicity and Apoptosis Induction Action in HCT116 Cells. Sci. Rep. 2018, 8, No. 288.

(9) Liu, K.-G.; Cai, X.-Q.; Li, X.-C.; Qin, D.-A.; Hu, M.-L. AreneRuthenium(II) Complexes Containing 5-Fluorouracil-1-Methyl Isonicotinate: Synthesis and Characterization of Their Anticancer Activity. Inorg. Chim. Acta 2012, 388, 78-83.

(10) Kitagawa, S.; Nozaka, Y.; Munakata, M.; Kawata, S. Synthesis and Crystal Structures of Tetra- and Hexanuclear Copper(I) Complexes of Pyrimidine Derivatives, [Cu4(C4H8N2S)4](ClO4)4 and [Cu6(C5H5N2S)6]. Inorg. Chim. Acta 1992, 197, 169-175.

(11) Shaheen, F.; Badashah, A.; Gielen, M.; Marchio, L.; de Vos, D.; Kaleem Khosa, M. Synthesis, Characterization and in Vitro Cytotoxicity of Homobimetallic Complexes of Palladium(II) with 2- 
Thiouracil Ligands. Crystal Structure of $[\mathrm{Pd} 2(\mathrm{TU})(\mathrm{PPh} 3) 3 \mathrm{Cl} 2]$. Appl. Organomet. Chem. 2007, 21, 626-632.

(12) Sce, F.; Beobide, G.; Castillo, O.; de Pedro, I.; Pérez-Yáñez, S.; Reyes, E. Supramolecular Architectures Based on P-Cymene/ Ruthenium Complexes Functionalized with Nucleobases. CrystEngComm 2017, 19, 6039-6048.

(13) Abid, M.; Shamsi, F.; Azam, A. Ruthenium Complexes: An Emerging Ground to the Development of Metallopharmaceuticals for Cancer Therapy. Mini-Rev. Med. Chem. 2016, 772-786.

(14) Meggers, E. Exploring Biologically Relevant Chemical Space with Metal Complexes. Curr. Opin. Chem. Biol. 2007, 11, 287-292.

(15) Renfrew, A. K. Transition Metal Complexes with Bioactive Ligands: Mechanisms for Selective Ligand Release and Applications for Drug Delivery. Metallomics 2014, 6, 1324-1335.

(16) Swaminathan, S.; Haribabu, J.; Kalagatur, N. K.; Konakanchi, R.; Balakrishnan, N.; Bhuvanesh, N.; Karvembu, R. Synthesis and Anticancer Activity of [ $\mathrm{RuCl} 2$ (H6-Arene)(Aroylthiourea)] Complexes-High Activity against the Human Neuroblastoma (IMR-32) Cancer Cell Line. ACS Omega 2019, 4, 6245-6256.

(17) Correa, R. S.; Bomfim, L. M.; Oliveira, K. M.; Moreira, D. R. M.; Soares, M. B. P.; Ellena, J.; Bezerra, D. P.; Batista, A. A. Ru(II) Complexes Containing Uracil Nucleobase Analogs with Cytotoxicity against Tumor Cells. J. Inorg. Biochem. 2019, No. 110751.

(18) Goitia, H.; Villacampa, D. M.; Laguna, A.; Gimeno, C. M. Cytotoxic Gold(I) Complexes with Amidophosphine Ligands Containing Thiophene Moieties. Inorganics 2019, 13.

(19) Thota, S.; Rodrigues, D. A.; Crans, D. C.; Barreiro, E. J. Ru (II) Compounds: Next-Generation Anticancer Metallotherapeutics? J. Med. Chem. 2018, 61, 5805-5821.

(20) Trondl, R.; Heffeter, P.; Kowol, C. R.; Jakupec, M. A.; Berger, W.; Keppler, B. K. NKP-1339, the First Ruthenium-Based Anticancer Drug on the Edge to Clinical Application. Chem. Sci. 2014, 5, 29252932.

(21) Kaspler, P.; Lazic, S.; Forward, S.; Arenas, Y.; Mandel, A.; Lilge, L. A Ruthenium(II) Based Photosensitizer and Transferrin Complexes Enhance Photo-Physical Properties, Cell Uptake, and Photodynamic Therapy Safety and Efficacy. Photochem. Photobiol. Sci. 2016, $15,481-495$.

(22) Mital, M.; Ziora, Z. Biological Applications of $\mathrm{Ru}(\mathrm{II})$ Polypyridyl Complexes. Coord. Chem. Rev. 2018, 375, 434-458.

(23) Renier, O.; Deacon-Price, C.; Peters, E. J.; Nurekeyeva, K.; Russon, C.; Dyson, S.; Ngubane, S.; Baumgartner, J.; Dyson, J. P.; Riedel, T.; et al. Synthesis and In Vitro (Anticancer) Evaluation of H6-Arene Ruthenium Complexes Bearing Stannyl Ligands. Inorganics 2017, 44.

(24) Colina-Vegas, L.; Oliveira, K. M.; Cunha, B. N.; Cominetti, M. R.; Navarro, M.; Azevedo Batista, A. Anti-Proliferative and AntiMigration Activity of Arene-Ruthenium(II) Complexes with Azole Therapeutic Agents. Inorganics 2018, 6, 132.

(25) Batista, A. A.; Santiago, M. O.; Donnici, C. L.; Moreira, I. S.; Healy, P. C.; Berners-Price, S. J.; Queiroz, S. L. Electrochemical and Spectroscopic Studies on $\mathrm{RuCl} 2(\mathrm{PPh} 3) 2(\mathrm{~N}) 2$ and $\mathrm{RuCl} 2(\mathrm{PPh} 3) 2-$ $(\mathrm{N}-\mathrm{N})$ Complexes $(\mathrm{N}=$ pyridine Derivatives and $\mathrm{N}-\mathrm{N}=$ phenanthroline or Bipyridine Derivatives). X-Ray Structure of RuCl2(PPh3)2(Phen). Polyhedron 2001, 20, 2123-2128.

(26) Corrêa, R. S.; Da Silva, M. M.; Graminha, A. E.; Meira, C. S.; Dos Santos, J. A. F.; Moreira, D. R. M.; Soares, M. B. P.; Von Poelhsitz, G.; Castellano, E. E.; Bloch, C.; et al. Ruthenium(II) Complexes of 1,3-Thiazolidine-2-Thione: Cytotoxicity against Tumor Cells and Anti-Trypanosoma Cruzi Activity Enhanced upon Combination with Benznidazole. J. Inorg. Biochem. 2016, 156, 153163.

(27) Oliveira, K. M.; Liany, L.-D.; Corrêa, R. S.; Deflon, V. M.; Cominetti, M. R.; Batista, A. A. Selective Ru(II)/Lawsone Complexes Inhibiting Tumor Cell Growth by Apoptosis. J. Inorg. Biochem. 2017, $176,66-76$.

(28) Corrêa, R. S.; da Silva, M. M.; Graminha, A. E.; Meira, C. S.; dos Santos, J. A. F.; Moreira, D. R. M.; Soares, M. B. P.; Von Poelhsitz, G.; Castellano, E. E.; Bloch, C.; et al. Ruthenium(II)
Complexes of 1,3-Thiazolidine-2-Thione: Cytotoxicity against Tumor Cells and Anti-Trypanosoma Cruzi Activity Enhanced upon Combination with Benznidazole. J. Inorg. Biochem. 2016, 156, 153163.

(29) Santos, A. F.; Ferreira, I. P.; Pinheiro, C. B.; Santos, V. G.; Lopes, M. T. P.; Teixeira, L. R.; Rocha, W. R.; Rodrigues, G. L. S.; Beraldo, H. [Ag(L)NO3] Complexes with 2-Benzoylpyridine-Derived Hydrazones: Cytotoxic Activity and Interaction with Biomolecules. ACS Omega 2018, 3, 7027-7035.

(30) Zehra, S.; Roisnel, T.; Arjmand, F. Enantiomeric Amino Acid Schiff Base Copper(II) Complexes as a New Class of RNA-Targeted Metallo-Intercalators: Single X-Ray Crystal Structural Details, Comparative in Vitro DNA/RNA Binding Profile, Cleavage, and Cytotoxicity. ACS Omega 2019, 4, 7691-7705.

(31) Wolfe, A.; Shimer, G. H.; Meehan, T. Polycyclic Aromatic Hydrocarbons Physically Intercalate into Duplex Regions of Denatured DNA. Biochemistry 1987, 26, 6392-6396.

(32) Ansar Ahmed, S.; Gogal, R. M.; Walsh, J. E. A New Rapid and Simple Non-Radioactive Assay to Monitor and Determine the Proliferation of Lymphocytes: An Alternative to [3H]Thymidine Incorporation Assay. J. Immunol. Methods 1994, 170, 211-224.

(33) Nicoletti, I.; Migliorati, G.; Pagliacci, M. C.; Grignani, F.; Riccardi, C. A rapid and simple method for measuring thymocyte apoptosis by propidium iodide staining and flow cytometry. J. Immunol. Methods 1991, 139, 271-279. 